\title{
Household Units in the Analysis of Prehistoric Social Complexity, Southern Cook Islands
}

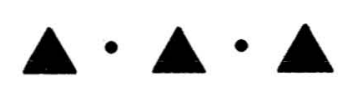

JULIE M. E. TAOMIA

HOUSEHOLDS, AND THE FAMILIES that comprise them, are the most basic units of social organization in any culture. While archaeologists may not be able to discuss the social composition of prehistoric households, the analysis of household remains allows archaeologists to discuss social organization across cultures and changes to it through time (e.g., Banning and Byrd 1987; Deetz 1982; Weeks 1988). As Brumfiel (1992) has noted, changes in a society at large are rooted in changes in the organizational composition and character of the households that provide the goods and services to support the society. This was particularly true in pre-industrial societies where most activities took place within the household and the context of family relationships. Archaeologists usually do not have access to the social relationships that made up the households that they study, but rather must examine the physical remains. People express information about themselves for themselves and for others through the composition and organization of their household space. The physical remains of households are the archaeological manifestation of this information and are a means by which archaeologists can discuss social organization. Aspects of social organization, including social stratification and inequality, have been used by archaeologists and anthropologists as measures of complexity. McGuire (1983) breaks down cultural complexity into heterogeneity and inequality in his approach to evaluating the complexity of cultures. He argues that most studies of cultural complexity have assumed a Marxian unilineal hierarchical stratification of the societies that may not be appropriate. He argues that his approach assumes no structuring principles. Heterogeneity is defined as the frequency of individuals among social parameters (McGuire 1983:101) and inequality as the extent of differential access to material and social resources (McGuire 1983:102). The range of variation in physical structure, materials, and artifacts that constitute the physical remains of prehistoric households can provide data for archaeologists to discuss such topics as the number of social personae, the distribution of the population among these social personae, and inequality between social personae (McGuire 1983). This approach is taken here in a study of archaeological remains from three of the Southern Cook Islands. When discussing

Julie Taomia is Senior Archaeologist at the American Samoa Historic Preservation Office, Pago Pago, AS.

Asian Perspectives, Vol. 39, No. 1-2, (C) 2001 by University of Hawai'i Press. 
archaeological household remains, the emphasis would be most fruitfully focused on the social persona of the household as a whole. Individuals are difficult to identify, and Cook Islands ethnography (e.g., Hiroa 1934) indicates that the household as a social group usually bore the status of its members. In addition, specialists, a social persona as discussed by McGuire, often use other members of their household and family in the practice of their craft. Because members of a household are frequently near to hand, many members of a household assist the specialist in the practice of their craft (Hiroa 1934; personal observation on Mangaia 1993). ${ }^{1}$ The results of an analysis sensitive to these issues can then lead to meaningful comparison with other societies or the same society at various points in time (see McGuire 1983).

The units that have generally been chosen by archaeologists and anthropologists as measures of complexity are biased against developmental studies because they are markers of existing complexity. Classic studies based on systemic models have had difficulty explaining the development of complexity because of the focus on the system rather than on human agency (Brumfiel 1992). When this approach is applied to less complex societies the impression of long-term stasis emerges. Physical remains that tend to attract archaeological attention in complex societies, such as monumental architecture, are absent from less complex societies. Research on Polynesian societies has tended to follow many of the same trends characterized by Brumfiel (1992) for research in other parts of the world. Research on complexity within Polynesian societies has also followed worldwide trends (e.g., McGuire 1983), and Polynesian societies have provided data in discussions of complexity (e.g., Sahlins 1958). Although rarely explicitly stated, the expectations that social positions should be ordered like a layer cake, with fewer people at the top holding positions that are clearly ranked in relationship to all other positions in the society (see McGuire 1983), have permeated research into prehistoric Polynesian social organization (see for example Kirch 1984, 2000). It has also been expected that ascent to positions of power would be unilinear.

The classifications of contact-era Polynesian social organizations highlight some of the issues in classic discussions of social complexity (Goldman 1970; Sahlins 1958). Both Sahlins and Goldman assumed that the number of unilineal hierarchically arranged levels of social positions indicated social complexity. Researchers (see for example Cordy 1981; Kirch 2000) have made these Marxian assumptions about the ordering of social positions without questioning their applicability to traditional Polynesian societies. Some Polynesian societies do not fit nicely into the proposed typologies and have fallen into an intermediate gray area, including one of the societies discussed here, Mangaia. Goldman viewed these intermediate societies as a step in the evolution of complexity (1970). This position has been criticized, though still within the unilineal hierarchical framework; Thomas, for example, has suggested that these societies represented a step away from cultural complexity (1989). These intermediate societies tend to have been those in which there were not unquestioned all-powerful leaders. Priests tended to be very powerful, as were warriors. Chiefly rank contributed to the acquisition of power and leadership positions but was not the only criterion. Achievement through the display and demonstration of personal power (mana) was decisive in choosing among similarly qualified candidates for leadership positions (see Douglass 1979).

McGuire (1983) has proposed a means of measuring complexity that does not 
assume any particular organizational form. The degree of heterogeneity and inequality are used to measure complexity. Heterogeneity is measured through the number of social personae and inequality by differential access to resources. Increase or decrease in one does not presuppose movement of the other. In his examples of archaeological analyses of past cultures using this approach, McGuire uses burial data and evidence from residential structures, the remains of prehistoric households.

\section{HOUSEHOLD RESEARCH IN POLYNESIA}

Not surprisingly, archaeologists studying Polynesian societies have identified the household as the basic unit of social organization in prehistory (e.g., Jennings et al. 1976; McCoy 1973). At the most basic, physical manifestations of Polynesian households consist of a sleeping house and a cooking area. Other structures may be associated with the household unit depending upon the society and the rank of household members. A wide variety of activities may also have been conducted in the vicinity of the sleeping house. Archaeological research throughout Polynesia has shown that this basic pattern can be expected across the large geographic area (to name a few: Cordy 1981; Jennings et al. 1976; McCoy 1973; Sutton ed. 1991; Weisler and Kirch 1985).

Attention has been focused on the information that household research can provide about social ranking within Polynesian societies, assuming a unilineal hierarchical model. Social status has been interpreted on the basis of the size of the sleeping house and/or other structures associated with it, the number and type of other structures associated with a sleeping house, and the organization of space around a sleeping house (see for example Cordy 1981; Sutton ed. 1991; Weisler and Kirch 1985). These factors are often indicative of social status, or social personae and inequality, but these are not the only factors, and the assumption of unilineal hierarchies can be problematic. Sutton and his colleagues have shown in the study of an unfortified settlement in New Zealand that the archaeologists' expectations for the physical expression of social status are not always met. The orientation of household units at the settlement provided information about the relative status of their prehistoric occupants (Sutton 1991). Artifacts and materials that were socially valuable and therefore would have been controlled by chiefs were found among the household remains of the specialists who produced those artifacts rather than as expected in the households of chiefs (Sutton 1991:196200).

There has been a tendency for researchers to characterize a typical house (e.g., McCoy 1976; Prickett 1982). Some of the theoretical frameworks developed and used by anthropologists studying cultures around the world lend themselves to this type of study with an emphasis on determining the structuring principles of a society (e.g., Bourdieu 1978; Hodder 1986; Moore 1986). While there is no doubt that all societies have general ideals regarding acceptable behavior and, in this case, household organization, a range of variation in practice is usually acceptable. If emphasis is placed on identifying the structuring principle, and on characterizing a "typical" structure or household unit, the range of variation is suppressed. In the analysis of societies with numerous social positions (e.g., highly heterogeneous societies; see McGuire 1983) and multiple means of access to power and/or 
wealth, this can lead to misrepresentations of the lived experience of the prehistoric people. Even in societies that appear to be organized in a unilineal hierarchical manner, this focus on typical structural types will suppress any variation and give the appearance of one guiding structure with no variation. Any culture change that occurred will be difficult to explain, particularly when the outcome has no clear precedent in the typical structures of the previous regime.

There are some practical reasons for the characterization of "typical" prehistoric houses or other structural remains. It can be useful for researchers to have some idea of the physical characteristics of a household for easy field identification. A "typical" form may aid in the interpretation of sometimes confusing and often-limited nonperishable material remains. Recognition of variability in the material remains of prehistoric households often requires good control on the distribution of artifacts across sites so that the nature of the variability between households can be characterized. The preferred method of acquiring this information is to locate all physical remains in situ rather than recovering artifacts and faunal remains in screens (e.g., Endicott 2000; Sutton ed. 1991). However, this method of excavation is both time consuming and expensive.

Some archaeological research in Polynesia has already shown that such "typical" house characterizations can be restrictive (e.g., Sutton ed. 1991). Analyses of variation in household remains have emphasized differences in function or status within the interpretive framework of unilineal social hierarchies (e.g., see Green 1984, 1991; Weisler and Kirch 1985). Sutton and his associates in New Zealand found that house form and artifact assemblages were less reliable indicators of status than were the proxemics of dwellings (Sutton ed. 1991). The physical remains of prehistoric households probably represent a diversity of aspects of social organization, and interpretations that recognize this will be richer.

\section{THE SOUTHERN COOK ISLANDS}

The points raised above will be illustrated in this paper with data from three of the Southern Cook Islands: Mangaia, Rarotonga, and Ma'uke (see Fig. 1). These three islands are closely related linguistically and culturally although at the time of European contact they were politically independent with only sporadic contact among them. Protohistoric Mangaian society was one society that has not fit well in classification attempts (Goldman 1970; Sahlins 1958).

Despite their physical proximity these islands vary considerably in their individual geography. Mangaia consists of an old volcanic cone (at least 17 million years old) that is encircled by a limestone balk, the remains of an old reef that was exposed approximately .9 mya when the emergence of Rarotonga resulted in the flexure of the Pacific Plate. The volcanic core of Mangaia, with a maximum elevation of $160 \mathrm{~m}$ above sea level, is characterized today by lateritic soil derived from decomposing basalt. Basalt of sufficient quality to make stone tools is present in dikes exposed by streams. The limestone, called makatea or raei, is riddled with solution caves. The streams pond against the steep inner cliffs of the limestone creating natural swamps and lakes. Late prehistoric settlement focused on the valley bottoms, which were inundated for taro cultivation.

As indicated above, Rarotonga is a much younger island. Bare basalt rock is still visible on the mountains that reach to a maximum of $658 \mathrm{~m}$ above sea level. 


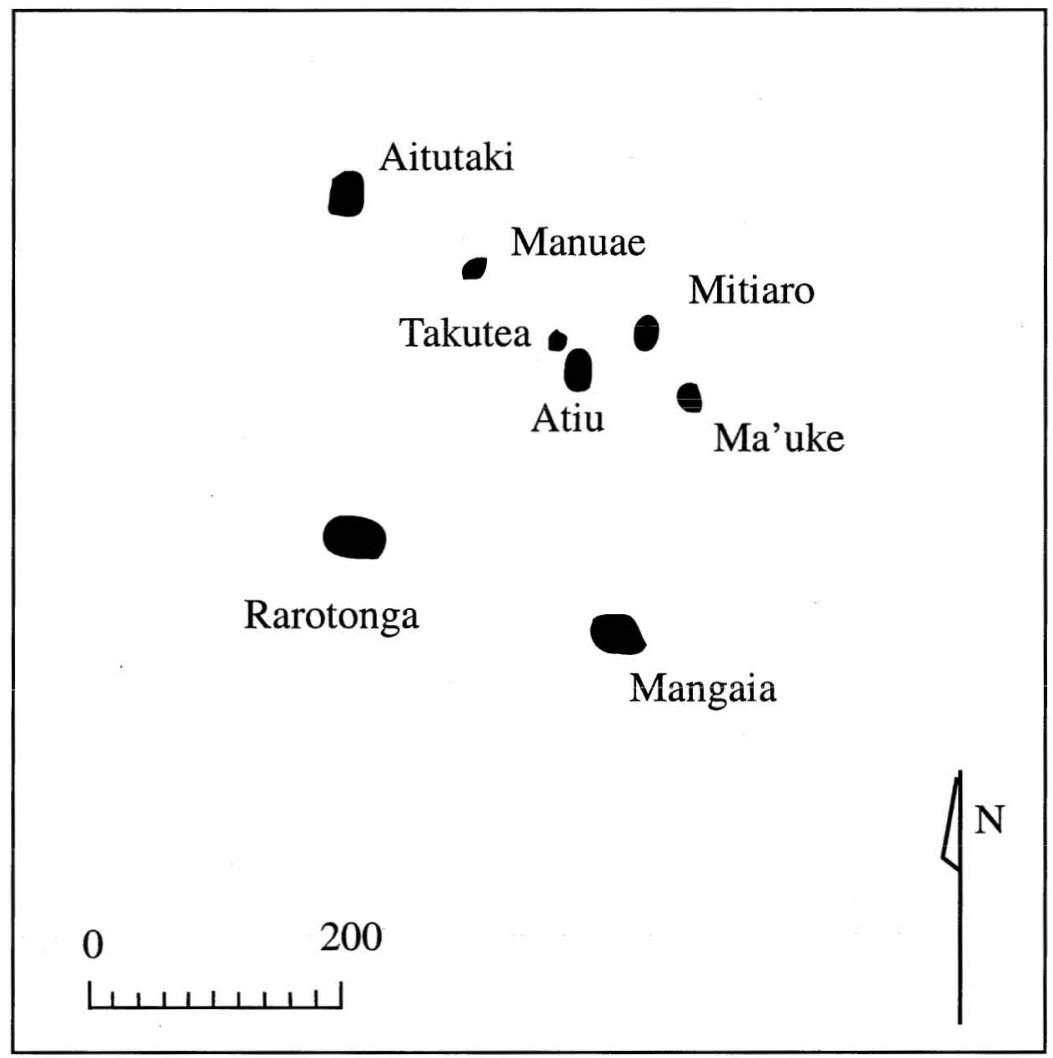

Fig. 1. Southern Cook Islands.

A coastal plain encircles the island. The valleys on this island were also the focus of prehistoric activity. However, on Rarotonga there is no makatea to block visual and physical access to the ocean, and prehistoric activities extended uninterrupted from the valleys to the ocean.

Ma'uke was also pushed up with the emergence of Rarotonga and is similar to Mangaia in its composition. Ma'uke is also comprised of a volcanic core surrounded by raised limestone makatea. The volcanic core stands $30 \mathrm{~m}$ above sea level. The transition from the makatea to the volcanic center is gradual. Swamps appear in patches rather than regular valley drainage systems. Late prehistoric settlement again focused on the swampy areas in which taro was cultivated.

In the ethnohistoric literature several authors have provided descriptions of Mangaian houses, with varying degrees of detail and utility to archaeologists. Most of these houses were probably sleeping houses and had other significant activity areas associated with them that were not recognized by European observers who interpreted the structures they saw as equivalent to European houses. Anderson on Cook's 1777 visit mentioned a coastal house, probably the residence of one of the ariki (on Mangaia supra-kin group priests; Beaglehole 1967:830). Only a general description is given of the exterior of the house. John Williams visited Mangaians at their residences in 1830, 1831, and 1833, several years after the first Christian teachers took up residence on the island. Williams provided 
some information in his journals regarding houses (Moyle 1984; Williams 1840). Hiroa provided detailed information about Cook Islands houses in his Arts and Crafts of the Cook Islands (1941) based to a large extent on information gathered on Mangaia although he also used data from other islands (Hiroa n.d.).

When Williams visited Mangaia in 1830 the Raiatean Christian teachers of the London Missionary Society and their small following of converted Mangaians were already building a village on the coast of both European-influenced lime plaster houses and "native houses." The yards of the teachers' houses were paved with rolled coral gravel (kirikiri) (Williams 1840). In his Samoan Journals (Moyle 1984), Williams described native plaster houses “... built after their own fashion i.e. very narrow, not exceeding eight feet in width; but so high in the middle that the rafters appear almost perpendicular" (Moyle 1984:24-25). Williams, Buzacott, and Makea of Rarotonga visited some of the "heathen" inland during the 1830 stop at Mangaia. Williams described "... a beautiful valley, around which the huts of the natives were erected" (Williams 1840:65). Williams visited a chief in 1833 and mentioned "... a broad pavement of stones in front of the house" (1840:67). The visitors on this occasion spent the night on mats spread over cut grass covering the floor inside the house. Wyatt Gill provided information about houses in passing in his translations of oral traditions $(1876,1894)$. His writings indicate walls and doors as structural features of Cook Island houses, and separate structures for children of chiefs on Mangaia.

Hiroa described houses and house construction in some detail in his Arts and Crafts of the Cook Islands (1944:34). He stated that

It was not usual to build raised stone platforms as sites for the houses, although paved terraces were sometimes made on sloping ground. In front of an important house, a rectangular area was defined with stones and filled in with coral gravel. Such an area was termed paepae. Sometimes a large flat stone was erected on the paepae with a slight lean to serve as a backrest.

Hiroa indicated that an average width for a house was about $11 \mathrm{ft}$, more if necessitated by the pitch of the roof or the requirements of the house. Hiroa identified a number of different types of Cook Island houses including sleeping houses, blanching houses ('are oka on Mangaia), elevated houses for favorite daughters, and canoe houses. As with the other sources, however, Hiroa did not provide any information on the range of variation within a given house type. $\mathrm{He}$ did indicate that there were important sleeping houses, but provided no explanation of what he meant by "important."

A lithograph in Gill (1876) showing "A mat hut in Mangaia" provides an illustration of what at least some houses may have looked like. However, it provides only one view of the area used by a household and therefore leaves many questions as to details of interest to archaeologists. It also shows no activity and few artifacts.

In his Dictionary of the Maori Language of Rarotonga, Savage notes a number of house types that might have been part of a household compound. These included 'are moe (sleeping house, which was and is applied to European-style dwelling houses), 'are umu (cook house), 'are vairanga 'apinga (store house), 'are pana (also 'are pori or 'are 'aka purotu; a blanching house for young people, especially daughters and generally associated with households of rank) (Savage 1990:40-41). Savage's 
definition of paepae supports Hiroa's as an open space around a house, often defined by stones set in the ground. He noted a connection between paepae and households of "persons of note," including but not necessarily limited to ariki, ${ }^{2}$ mata'iapo, rangatira, and priests (1990:218).

These ethnographic accounts do provide useful information for archaeologists to use in the interpretation of physical remains. However, these accounts tend to describe individual or "typical" structures and do not provide information about either details or the range of variation. They also tend to focus on aspects that do not survive in the archaeological record. These ethnohistoric descriptions can provide working hypotheses for archaeologists regarding likely physical components of prehistoric households.

\section{Archaeological Houses}

The remains of several prehistoric households have been excavated on Mangaia, Rarotonga, and Ma'uke. Several time periods are represented. Of nine terraces excavated on Mangaia in 1992 and 1993 under the direction of the author, only two can be identified with certainty as habitation sites (see Endicott 2000). A third site is discussed here because it may also represent prehistoric habitation, though insufficient area was excavated to determine this with certainty. Prehistoric household units were located on flat terraces cut into the ridge slopes surrounding the inundated valley floors where taro was cultivated. However, other activities including dry agriculture and community social events also took place on some of these terraces. Due to the movement of sediment onto the terraces from the slopes above and the lack of volcanic rock on the island for use in construction, functionally different sites appear similar on the surface and therefore excavation is required to identify variation in past use. This adds to the timeconsuming nature of household archaeology on Mangaia.

The three sites discussed here are within about a $50 \mathrm{~m}$ area in Veitatei Valley on the southwestern side of Mangaia (see Fig. 2). Both of the habitation sites have been disturbed by modern road construction that removed portions of each. The sites have all continued to be used by Mangaians who now live primarily in three coastal villages but return inland for agricultural activities. Cultivation has continued on many terrace sites, as has some residence and animal husbandry. The top $10-20 \mathrm{~cm}$ on most terraces is disturbed due to these activities. The sites were excavated by stratigraphic layer with the goal of recovering artifacts and other portable remains in situ. Screening was initially tested but the excavators removed all remains during excavation and none was identified in the screens. Therefore most of the excavations were conducted without screens. Physical remains were plotted horizontally and vertically using tape measures, line levels, and in some cases an alidade. Radiocarbon dates indicate that the layers of the sites discussed here were contemporary and date to late Mangaian prehistory (see Endicott 2000).

Excavations at site MAN-92 revealed a rolled coral gravel and limestone slab pavement, numerous postholes, and many fire pits. Several limestone facing slabs were found on the eastern end of the southern side of the pavement. One of these was exposed in the road cut in 1991 and was gone when the 1992 excavations commenced. Some unique features in the second stratigraphic layer (below 


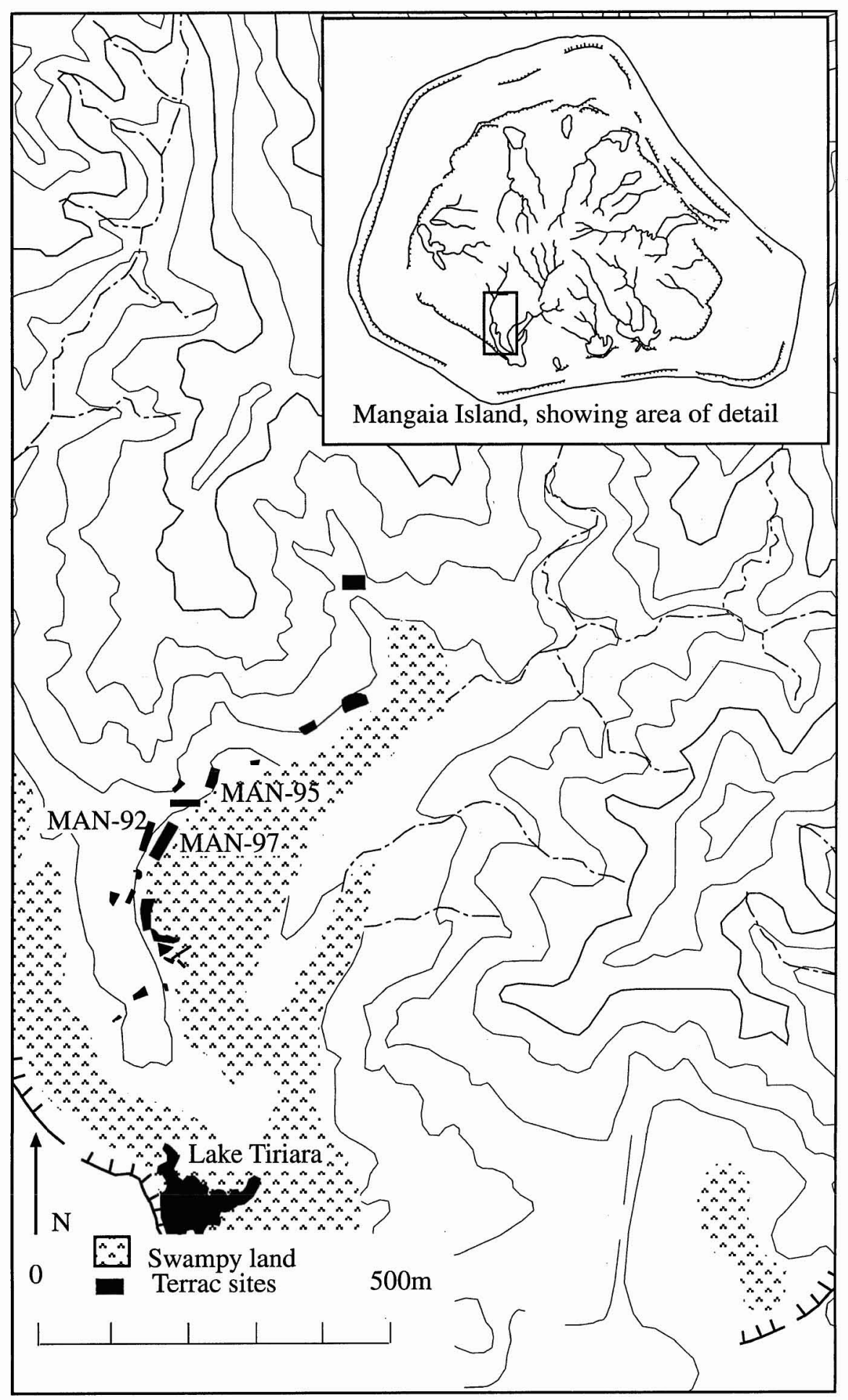

Fig. 2. Terraces in Veitatei Valley. 


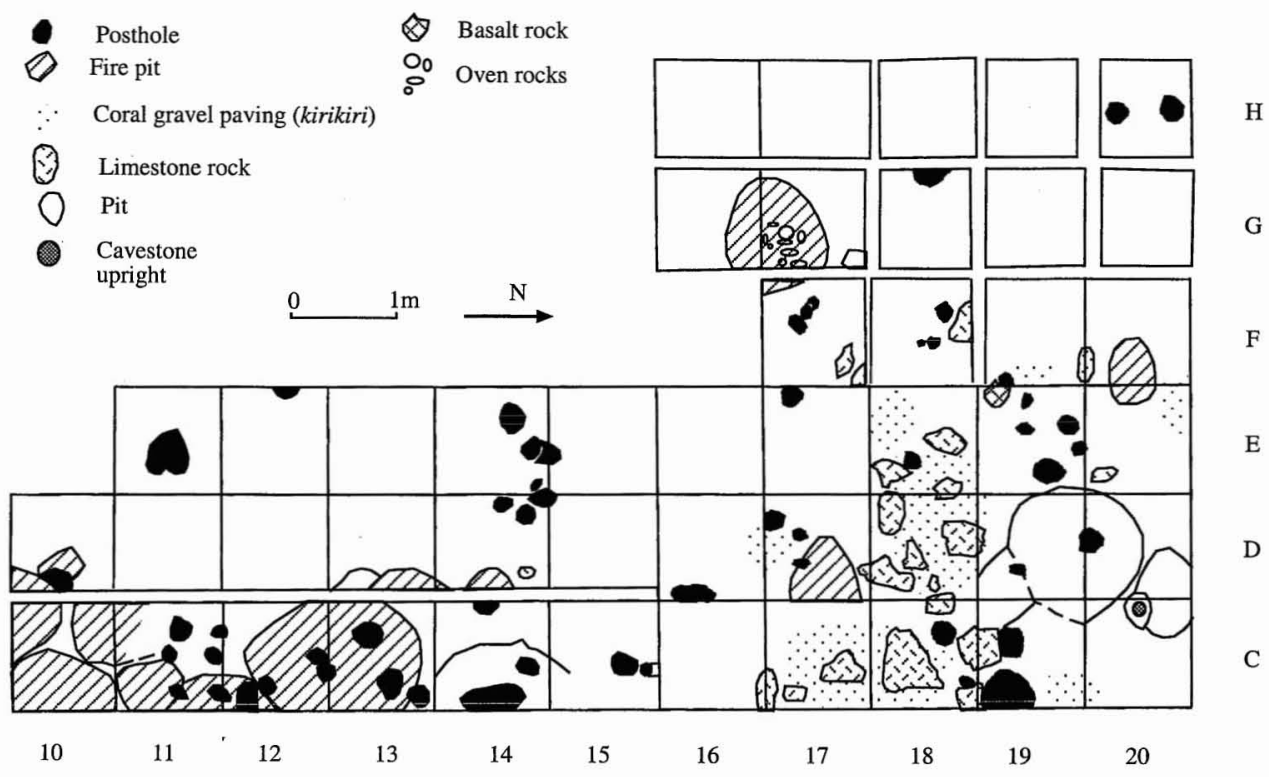

Fig. 3. MAN-92 layer 2 plan.

about $20 \mathrm{~cm}$ ) included a vertical calcite (stalactite or stalagmite) upright on the northern side of the paved area (see Fig. 3) and a chert cache to the west of the pavement near an earth oven (unit G17). The postholes indicate a number of possible structures, rebuilt or repaired over time. The postholes vary in size; some may represent supporting posts for roof beams while others may have been the smaller vertical poles that formed the walls. There appears to have been a structure to the south of the pavement and possibly one sitting over the pavement. This latter may have been unwalled.

Few artifacts were recovered from MAN-92. Aside from the chert cache, chert flakes were located around the chert cache and the adjacent earth oven, and around postholes south of the paved area. Basalt flakes were recovered around the chert cache and adjacent earth oven, around the postholes south of the paved area, and south of the postholes. An adze flake, a retouched flake, and an unpolished adze (preform), all basalt, were found between the postholes and the paved area. These artifacts probably represent both activity areas and cleaning patterns. Those flakes around postholes, out of the main areas of foot traffic, were probably removed from their original location by cleaning activities while artifacts found in more central locales and around fire pits may represent their actual locus of use.

MAN-97 is downhill and across the modern road from MAN-92. Fire pits and postholes were recorded at this site (Figs. 4 and 5). The upper layer (layers 1a and 1b) was contemporary with Layer 2 at MAN-92 (A.D. 1655). No coherent layer of coral gravel paving was evident in the portion of this site that was excavated, and the only likely structures were those sheltering the fire pits. More artifacts were recovered from this layer than from Layer 2 at MAN-92, likely resulting from more stone working or more use of stone tools. Artifacts again tended to cluster around the fire pits. Broken adze preforms and adze flakes were present at 
C

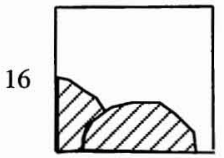

17

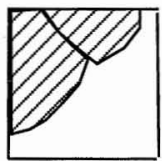

18

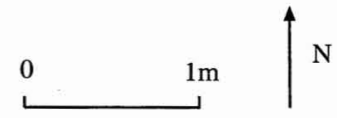

E
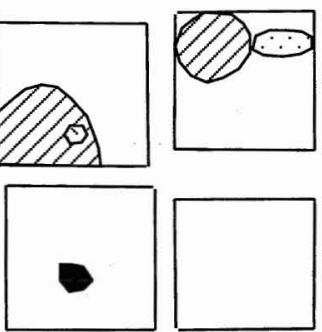

$\mathrm{N}$
F
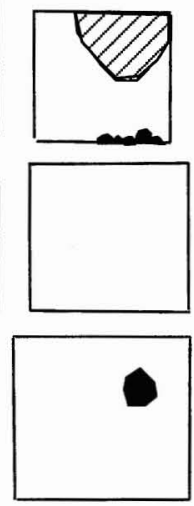

Fire pit

D Posthole

Q Limestone

Basalt

- Earth oven rakeout

Fig. 4. MAN-97 layer 1a plan.

C

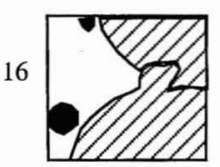

17

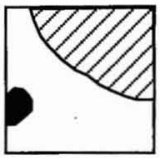

18
D
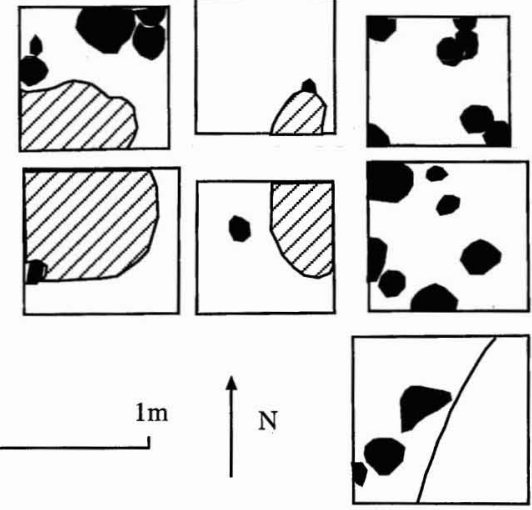

F

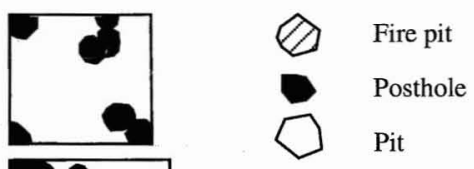

Fig. 5. MAN-97 layer $1 \mathrm{~b}$ plan.

the site, making it likely that these tools were made and used at the site. Faunal remains including fish and pig indicate that meals were eaten here, and the deep fire pit in layer $1 \mathrm{~b}$ indicates that some form of residence is likely to have taken place at this site. Further excavations are likely to find the remains of other structures associated with a household unit at this site.

MAN-95 is a flat terrace cut into the ridge slope about $50 \mathrm{~m}$ northeast of the other two sites. The eastern portion of MAN-95 was removed in road construction. The top $30 \mathrm{~cm}$ were excavated across the site. A radiocarbon date indicates that this layer was laid down between 1655 and 1950. A midden area is present in the southern portion of this site characterized by a large quantity of fire-cracked rock. A coral gravel (kirikiri) pavement with a piece of limestone embedded at the northern end was to the north of the midden area (see Fig. 6). A cache of eight adzes was found adjacent to the limestone. Some small postholes were present in 

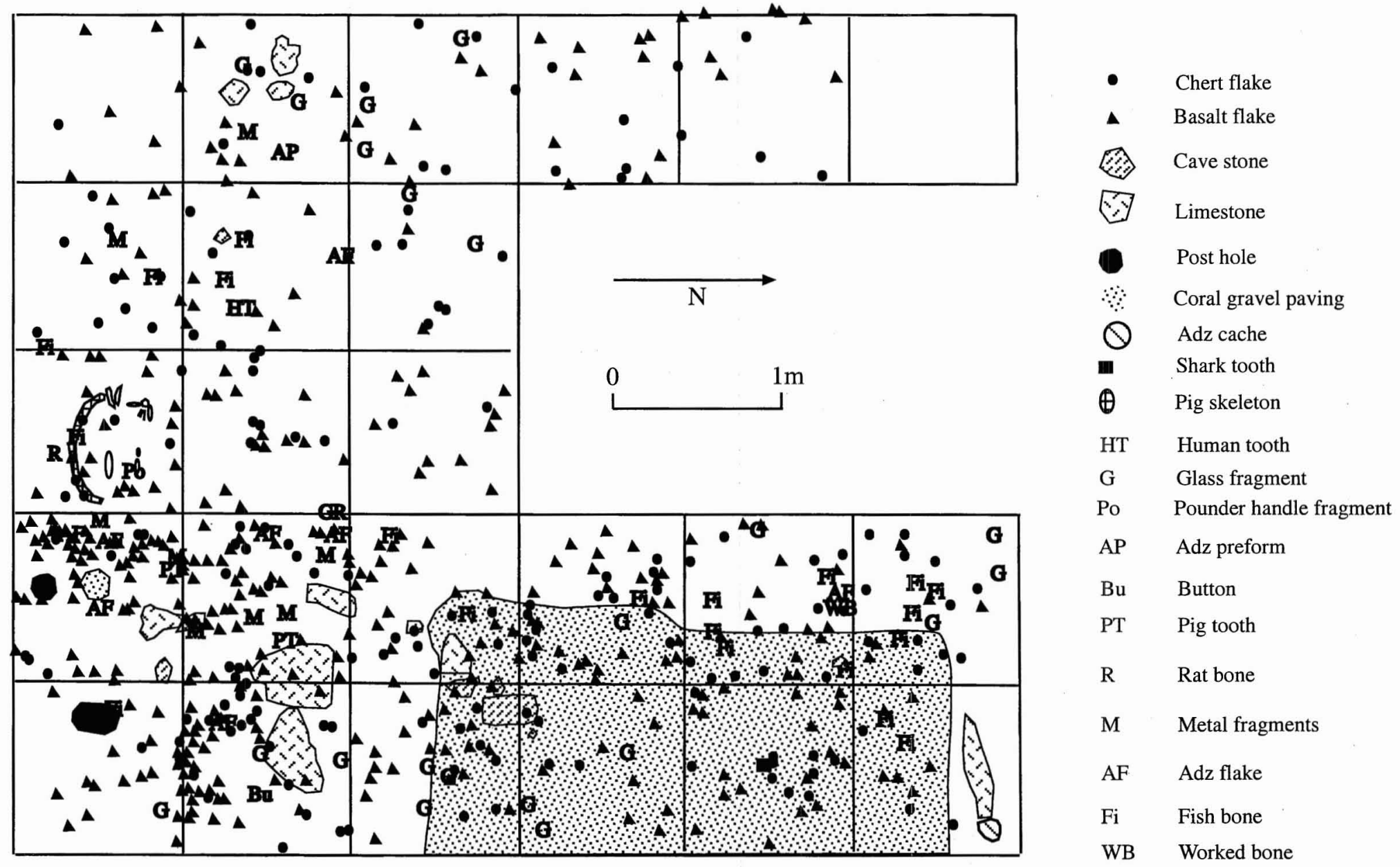

Fig. 6. MAN-95 layer 1 plan. 
Table i. Late Prehistoric Mangaia Habitation Site Artifacts

\begin{tabular}{|c|c|c|c|c|c|c|}
\hline \multirow{2}{*}{$\begin{array}{l}\text { SITE, LAYER, } \\
\text { AND AREA }\end{array}$} & \multicolumn{2}{|r|}{ BASALT } & \multirow{2}{*}{$\begin{array}{l}\text { CHERT } \\
\text { FLAKES }\end{array}$} & \multicolumn{2}{|c|}{$\begin{array}{c}\text { HISTORIC } \\
\text { ARTIFACTS }^{\mathrm{a}}\end{array}$} & \multirow[b]{2}{*}{ OTHER } \\
\hline & FLAKES & OTHER & & METAL & GLASS & \\
\hline \multicolumn{7}{|l|}{ MAN-92 Layer 2} \\
\hline Southern area & 29 & $\begin{array}{l}1 \text { adze flake } \\
1 \text { retouched flake }\end{array}$ & 3 & 0 & 0 & 0 \\
\hline Central area & 1 & 1 adze preform & 0 & 0 & 0 & 0 \\
\hline Eastern area & 2 & $\begin{array}{l}1 \text { adze fragment } \\
1 \text { hammerstone }\end{array}$ & 35 & 0 & 0 & 0 \\
\hline Total & 32 & 5 & 38 & 0 & 0 & 0 \\
\hline \multicolumn{7}{|l|}{ MAN-97 } \\
\hline Layer 1a & 35 & 1 scraper & 62 & 1 button & 1 & 1 plastic button \\
\hline Layer 1b & 31 & $\begin{array}{l}2 \text { adze flakes } \\
1 \text { broken adze } \\
\text { preform }\end{array}$ & 38 & 0 & 0 & 0 \\
\hline Total & 66 & 4 & 100 & 1 & 1 & 1 \\
\hline MAN-95 Layer 1 & 686 & $\begin{array}{l}7 \text { adze flakes } \\
8 \text { complete adzes } \\
6 \text { cores } \\
2 \text { broken adzes } \\
2 \text { adze preforms }\end{array}$ & 406 & 8 & 20 & $\begin{array}{l}1 \text { calcite pounder } \\
\text { handle fragment }\end{array}$ \\
\hline Total & 686 & 25 & 406 & 8 & 20 & 1 \\
\hline
\end{tabular}

${ }^{\mathrm{a}}$ Metal and Glass artifacts are fragments unless otherwise noted.

the paved area, normally identified after the layer of kirikiri had been removed as circles of coral gravel. These were all small and most likely supported a roof for shade rather than an actual sleeping house.

Many more artifacts were recovered from MAN-95 than at either MAN-92 or MAN-97 (see Table 1). Artifact densities were measured in the number of artifacts per cubic meter. Overall the highest densities of basalt flakes at MAN-95 were in the midden area, although the single unit with the highest basalt flake density was in the kirikiri area. The kirikiri area in general had high densities of basalt flakes. Four adze flakes, one small adze, and two broken adzes were found in the midden area, while two adze flakes and two adze preforms were recovered from the kirikiri area. And, of course, the adze cache was in the northeast corner of the excavated kirikiri area. The highest density of chert was found in the kirikiri area; the midden deposits had only slightly lower densities. There was a notable difference in the size of flake found between these two parts of the site, with more large flakes in the midden area and more small flakes in the kirikiri area. This indicates removal of the largest flakes from an area of foot traffic and seating. Five shark teeth, noted by Hiroa (1934) as carving tools, were present in the kirikiri area. Other artifacts recovered from MAN-95 include the handle portion of a broken calcite pounder (in the midden area) and purposefully cut large mammal long bones (in the kirikiri area). In general, only small animal bones (mostly fish) were present in the kirikiri area, while both large and small animal bones were 
found in the midden area, including a small pig skeleton lacking its cranium and mandible.

There are some similarities between MAN-95 and MAN-92. Both sites have coral gravel paving, and at both sites limestone slabs were imbedded vertically in the ground, probably as threshold or facing slabs. There are also marked differences. No paving stones were used and the earth ovens were not located at MAN-95, though the quantity of fire-cracked rock indicates that they were present at this site. No midden area was located at MAN-92 though excavations were carried as far south as possible. The limestone slabs were located at opposite cardinal directions in relation to the coral pavements at the two sites. Paving stones were only present at MAN-92. Only small postholes indicating less substantial structures were located at MAN-95 whereas the postholes at MAN-92 probably represent substantial structures. MAN-95 contained many more artifactual remains of all types than did MAN-92.

While this is only a sample of three, it does indicate variation in the type and intensity of activities that could take place at habitation sites. The differences in artifact types and quantities at the sites are also significant and unlikely to be the result of preservation conditions. MAN-95 most likely was the residence of a carver who may have made and repaired his own tools (adzes). The chert flakes may have been used for fine carving detail or processing plant fibers such as those used to lash adze heads to handles. The artifacts at MAN-92 and MAN-97 may represent a more standard household with a few adzes and flakes for household tasks. Future research will help to determine if the chert cache is unusual and therefore indicative of a social persona.

Several habitation areas have been excavated on Rarotonga. Parker reports excavations at habitation sites in the late 1960s and early 1970s (Trotter 1974:47$53,54-62,70-79)$. The focus of these excavations tended to be pavements, and in general the pavements alone were exposed. At the Vaiakura site, postholes were identified on the pavement, and Parker suggests some possible house forms. Large post molds or small pits (the latter is Parker's interpretation) were uncovered to the west of the pavement. Artifacts recovered included both historic and prehistoric materials (the latter consisting of adzes and a fragment of a calcite pounder). No radiocarbon dates were obtained, but given the artifact assemblages and the identification by surface remains it is probably late prehistoric with occupation extending into the historic era. The excavations in the Upper Maungaroa Valley on an earthen terrace behind a pavement (UM3 and UM4) revealed many postholes outlining a rectangular house, but no artifacts. No artifacts are mentioned in the excavations on the paved parts of this site either. Dates from these structural remains of a probable household unit span A.D. $1500 \pm 60$ to A.D. $1620 \pm$ 60. Excavations were conducted primarily over pavement at paepae Pokata; the postholes identified did not clearly outline a structure. The house of $\mathrm{Pa}$ Ariki is said to have stood behind the paepae, and a modern house used the pavements as approach paths at the time of the excavations. This site is also probably late prehistoric. Finally, excavations at 'Are Rangi revealed large postholes along one edge of the pavement. These were filled with lime, indicating that they represent at least in the final stage of occupation a historic lime-plastered house.

Bellwood conducted an intensive survey in Maungaroa Valley, and excavated a few habitation sites in the 1970s (1979). He also excavated areal exposures at Ngati 
Table 2. Bellwood's Classification of Habitation Sites (i978: i)

Tiare in Avarua, the location of an adze cache find several years earlier. Based upon his surface survey Bellwood identified four types of paepae, presented here in Table 2. The classification emphasizes the pavement, which according to Hiroa (1934) and Savage (1990) is the definition of the term paepae. Type A2 included both pavements without an approach path and small paved areas that appear quite different in form from both the others in this category and the other paepae categories, giving the appearance of a catch-all category. One structural feature that Bellwood noted but did not take into consideration in his evaluation of paepae typology was the small pavements to one side of the main paved area giving an "L" appearance to these sites. They appear with both type A1 and type A3 paepae.

Bellwood excavated a type A1 structure (RAR 51/10) in Lower Maungaroa Valley, including both the main paved area and the small side pavement as well as the earthen area enclosed by them. An associated hearth dated to A.D. $1750 \pm 90$. No artifacts were recovered. Bellwood proposed that the postholes represented a house that covered both the earthen area and the paved area in front. Bellwood also conducted excavations in the Upper Maungaroa Valley on a type A4 structure (RAR 53/6) that dated to around A.D. 1600, again proposing that the structure had extended over the pavement as well as the rectangular earthen area (Bellwood 1978:49). Bellwood noted that no hard trampled floor was found in either case. However, if these were sleeping houses as described earlier, the floor would have been covered with cut grass, making a hard earthen floor unlikely. Figure 7a (after Bellwood) shows the plan of the excavation with the postholes at the A4 site. Figure $7 \mathrm{~b}$ shows a cross section of the house as proposed by Bellwood, and Figure 7c shows a cross section based upon descriptions by Hiroa (1944, n.d.). Along line $\mathrm{B}$ indicated in the figures there are many postholes; Bellwood suggests that this indicates the center posts that supported the ridge pole, and that the three postholes behind this represent a platform. A comparison with Hiroa's descriptions of houses indicates that it is more likely that the fewer postholes (line C1) represent the posts that supported the center ridge line and the many postholes (line B) more likely represent the front wall of the house. The postholes on the pavement probably supported a roof that shaded the veranda. The lithograph from Gill discussed above also raises some questions regarding the orientation of houses. Bellwood appears to assume that entrances to houses were on the long axis of the house; given some of the physical remains, such as paths, this is understandable. However, the pavement in the lithograph has an L-shaped appearance with the entrance on the short axis of the house. The locations of physical remains and the patterns of their distributions across household space may help to answer such questions. Bellwood found two slingstones and a polishing stone on this site, but no horizontal location is provided. 
a)

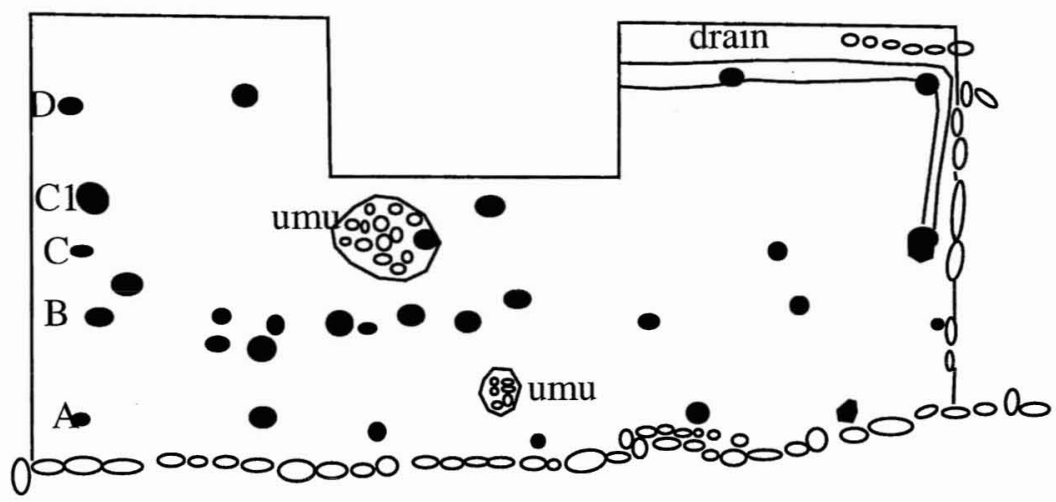

- Post holes Stone (unspecified)

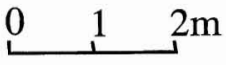

b)

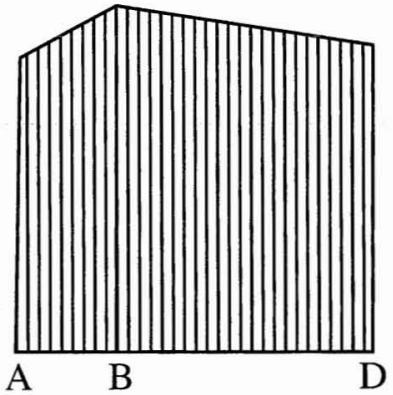

c)

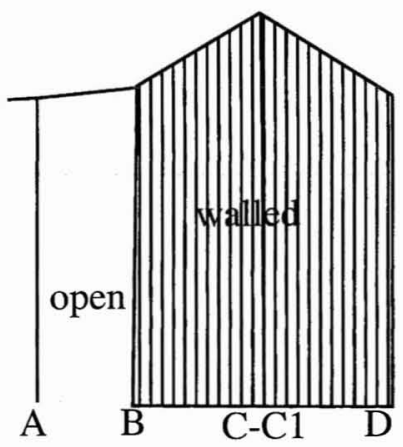

Fig. 7. a: Plan view of RAR53/4 after excavation (after Bellwood 1978); b: Cross section of proposed house at RAR53/4 based on Bellwood 1978 text; c: Cross section of proposed house at RAR53/4 based on Hiroa (1944, n.d.). Scale applies to all three figures.

Bellwood also conducted excavations at the Ngati Tiare site in Avarua (RAR 40), adjacent to the Vaikapuangi stream and near the coast (not more than $350 \mathrm{~m}$ away). He found several layers representing prehistoric activities. Although $42 \mathrm{~m}^{2}$ were excavated, no complete structures were exposed and hence interpretation of the remains is challenging. The deepest habitation layer, layer 4, dating between A.D. 1160 and 1380 (Bellwood 1978:69), contained primarily hearths and burned rock. Two pearl shell fishhook shanks and three primary volcanic (basalt) flakes were found. Volcanic and coral rock paved thresholds were associated with postholes in layer 3 and dated to around A.D. $1297 \pm 73$ (Bellwood 1978:70). Bellwood proposed two thresholds for this structure on the east and west sides, an unusual feature for contact-era Cook Island houses. Fire pits were also present near this pavement, and some postholes that may indicate a structure over two fire pits. Two pearl shell fishhook blanks were found, one in the cookhouse area and one in a possible rubbish pit. There were three complete adzes in the vicinity 
of the apparent cookhouse, one near the sleeping house, and one adze butt was found in the oven stones. A perforated Semele shell was located inside the sleeping house. Two adze flakes were also recovered but no provenience given. The late prehistoric occupation in layer $2 \mathrm{~b}$ was evidenced by postholes and fire pits. A dense deposit of kirikiri was located within the area outlined by postholes. Two pearl shell fishhook blanks were found outside of the proposed house, a trolling hook point just outside, and two blanks were found inside the house. A finished adze was found near a fire pit. Four basalt cores, 22 basalt flakes, 2 retouched flakes, 5 other adzes, and 1 "hand ax" were also found in layer $2 \mathrm{~b}$ but no horizontal location information is provided for these artifacts. One adze, 1 broken adze bit, 28 basalt flakes, and 1 core were found in layer $2 \mathrm{a}$ in which no structural remains were identified. While this information indicates that tool use, modification, and possibly manufacture took place at this site, the limited area of the excavations makes interpretation of the structures and work areas difficult. There appears to have been a shift to an increased use or manufacture of basalt tools at this site in late prehistory, represented by layer 2 .

The physical remains from the Rarotongan sites vary considerably. Few artifacts were recovered from the pavements excavated by Bellwood and the Canterbury Museum researchers (see Table 3). The adzes recovered from the Vaiakura site may indicate the residence of a wood carver early in the occupation of the

Table 3. Rarotongan Habitation Site Artifacts

\begin{tabular}{|c|c|c|c|c|c|}
\hline \multirow[b]{2}{*}{ SITE } & \multirow[b]{2}{*}{ LAYER } & \multicolumn{2}{|r|}{ BASALT } & \multirow[b]{2}{*}{ SHELL } & \multirow[b]{2}{*}{ OTHER } \\
\hline & & FLAKES & OTHER & & \\
\hline RAR-40 & $2 a$ & 28 & $\begin{array}{l}2 \text { adzes } \\
1 \text { basalt core }\end{array}$ & & \\
\hline RAR-40 & $2 \mathrm{~b}$ & 23 & $\begin{array}{l}6 \text { adzes } \\
1 \text { retouched flake } \\
1 \text { hand axe }\end{array}$ & $\begin{array}{l}2 \text { pearl shell blanks } \\
1 \text { pearl shell fishhook }\end{array}$ & \\
\hline RAR-40 & 3 & 0 & 5 adzes & 2 fishhook blanks & $\begin{array}{l}1 \text { perforated Semele } \\
\text { shell }\end{array}$ \\
\hline $\begin{array}{l}\text { RAR-40 } \\
\text { RAR-51/10 }\end{array}$ & 4 & 3 & & 2 fishhook shanks & \\
\hline RAR-53/6 & & & 2 basalt slingstones & & $\begin{array}{l}1 \text { sandstone } \\
\text { polishing stone }\end{array}$ \\
\hline RAR-53/1 & & & & & \\
\hline RAR-53/2 & & & & & \\
\hline $\begin{array}{l}\text { RAR-53/3 } \\
\text { RAR-53/4 }\end{array}$ & & & & & \\
\hline Vaikura & Surface & & Several adzes & & \\
\hline Vaikura & 1,2 & & & & $\begin{array}{l}1 \text { calcite pounder } \\
1 \text { iron fish spear } \\
1 \text { iron bolt } \\
1 \text { piece iron sheet }\end{array}$ \\
\hline Vaikura & 3 & & & & $\begin{array}{l}\text { Glass fragments and } \\
\text { wire }\end{array}$ \\
\hline Vaikura & 4 & & & & Iron fragments \\
\hline Vaikura & 16 & & 2 adzes & & \\
\hline 'Are Rangi & Surface & & 2 adzes & & \\
\hline
\end{tabular}


site. The Upper Maungaroa settlement is said to have been a refuge, where slingstones might be expected. The polishing stone may indicate adze use. The lack of artifacts at the other sites might indicate the status of the prehistoric occupants or be a reflection of the locales chosen for excavation. It is unlikely that even the households of high status individuals would not have earth ovens, and at the Mangaian sites artifacts tended to cluster around the fire pits. The remains at the Ngati Tiare site are much more like those found at the Mangaia sites; where the horizontal provenience of artifacts was noted at Ngati Tiare they tended to be near fire pits, with fire-cracked stones, or on or near pavements. Some of the variation in artifacts may be related to environmental factors, as the Ngati Tiare site contains sand in which shell artifacts survive better than in the clay characteristic of the other Rarotongan as well as the Mangaian sites. Bird, fish, and mammal bone did survive in the clayey sites on Mangaia, and fishhook blanks are present in layer 2 at Ngati Tiare, which was significantly more clayey than the lower deposits.

As noted above, Bellwood was able to develop a classification of house remains on the basis of their surface manifestations. Presumably the residential sites consisting of paved verandas and approach paths required more effort to construct and therefore the coordination of a larger group of people, than those with stonefaced earthen terraces. However, as some of the sites without paths have a greater recorded ${ }^{3}$ area than those with paths, the relationships between the structural features and the social position of the people who lived there remain unclear (see Endicott 2000:215-225). Further archaeological research on Rarotonga may reveal that certain house types were associated with particular social personae.

On Ma'uke late prehistoric settlement sites are in the interior on volcanic sediments close to the swamps that were prized for cultivation. Surface scatters of kirikiri, ash, and broken oven stones indicate these sites. Walter excavated at a coastal site, Anai'o, assuming that the inland sites had been severely disturbed and would not yield much information (Walter 1993). In addition, they were assumed to be late and not pertinent to the project goals of studying the settlement and early occupation of the island.

The excavations at Anai'o yielded structural remains that date to the late fourteenth century A.D. according to radiocarbon dates. ${ }^{4}$ Like the researchers on Rarotonga, Walter also appears to have expected to find sleeping houses built

Table 4. Anai'o Habitation Site Artifacts, Máuke

\begin{tabular}{|c|c|c|c|c|c|}
\hline \multirow{2}{*}{$\begin{array}{l}\text { STRUCTURE } \\
\text { NUMBER }\end{array}$} & \multicolumn{2}{|c|}{ BASALT } & \multicolumn{2}{|r|}{ SHELL } & \multirow[b]{2}{*}{ OTHER } \\
\hline & FLAKES & OTHER & FLAKES & OTHER & \\
\hline 1 & Present & 1 coconut grater ${ }^{\mathrm{a}}$ & Present & 3 fishhook blanks & 7 abraders \\
\hline 2 & Present & 1 adze & Present & 2 fishhook blanks & 4 abraders \\
\hline 3 & Present (dense) & 2 adzes & Present & 1 fishhook blank & 1 abrader \\
\hline 4 & & & Present & & \\
\hline 5 & Present (dense) & & Present & 1 fishhook blank & 1 slingstone \\
\hline
\end{tabular}

${ }^{a}$ Material is not indicated in text or illustration available, but given that "coconut graters" in other parts of Polynesia are basalt it is assumed here that the distinction between a coconut grater and a coconut scraper is between basalt and pearl shell materials, respectively. 
over pavements, and his interpretations of the remains reflect this expectation. Walter numbered the structures 1-5, and interprets at least two of them as sleeping houses. Insufficient area was exposed on a sixth structure to allow interpretation. Structure 1 was paved in kirikiri (waterworn coral gravel) and had sparse midden debris, ash, and oven rocks scattered across the pavement. Walter identified an outline of rock along the northern edge as a narrow paepae, but it is not very clear. There is a shell working area at the western end of the paepae with pearl shell waste flakes, abraders, and fishhook blanks. Hearths were present within this area. Excavations were not extended far enough to determine if a structure had been built over an earthen floor adjacent to the pavement. Structure 2 had a denser kirikiri spread, and fish and mammal bones were also present. A basalt flake and a polished adze were found to the north of the kirikiri pavement; a fishhook, fishhook blank, fragments of worked pearl shell, and an abrader were also found in the vicinity. Walter proposes that both of these structures may have been cookhouse areas. Structure 3 consisted of an earthen floor outlined in coral slabs that were vertically embedded in the ground, with a kirikiri pavement to the south. A stone working area was identified to the south. This structure was interpreted as a dwelling house. Structure 4 consisted of a kirikiri pavement with some postholes and evidence of shell working. Coral slabs on the prehistoric surface adjacent to a deep fire pit $(u m u)$ represented Structure 5. Evidence of shell and stone working was present in this area as well. These two structures are interpreted as components of a household unit, with Structure 4 the sleeping house and Structure 5 the cooking area. Although large areas were excavated at this site, none of the structures was completely exposed. Most of the activity areas appear in similar locales to those on Mangaia-on pavements, adjacent to fire pits, next to the outside walls of structures. Extensive stone working was evident on the pavement associated with Structure 3, comparable to the remains at MAN-95.

\section{DISCUSSION}

The structural remains discussed above include two sets of roughly contemporary remains from three of the Southern Cook Islands. The two sites excavated in the Maungaroa Valley by Bellwood and those reported by Parker were roughly contemporary with the two on Mangaia and probably with layer $2 \mathrm{~b}$ of the Ngati Tiare site. The structural remains at Anai'o on Ma'uke were probably contemporary with the first two habitation layers at Ngati Tiare, given the error in radiocarbon ages.

The earlier period is represented at only two sites, Anai'o on Ma'uke and Ngati Tiare on Rarotonga. The excavations of layer 4 at the Anai'o site on Ma'uke uncovered one household unit (a probable sleeping house and a cookhouse) with evidence of fishhook manufacture (Structures 4 and 5). Basalt flakes were primarily associated with the earth oven. Many more basalt flakes and some adze preforms were found on the pavements and just within the rock outline of Structure 3, and this may have been the working locus of an adze manufacturer. Evidence of fishhook manufacture was also present at the structure indicating fishhook manufacture as well as stone working. The relationship among Structures 3,1, and 2 is not clear. There is no clear evidence of ranking between the two probable sleeping houses at this site. One may have been the residence of an 
Table 5. Radiocarbon Dates from Cook Island Habitation Sites

\begin{tabular}{|c|c|c|c|c|}
\hline SITE & LAYER & FEATURE DATED & MATERIAL & DATE $^{a}$ \\
\hline \multirow{2}{*}{$\begin{array}{l}\text { Ngati Tiare } \\
\text { (RAR-40) }\end{array}$} & 4 & Fire pit (F3) & Charcoal & A.D. $1230 \pm 70$ (ANU) \\
\hline & & Pit (F7) & Charcoal & A.D. $1320 \pm 60$ (NZ) \\
\hline \multirow[t]{2}{*}{$\begin{array}{l}\text { Ngati Tiare } \\
\text { (RAR-40) }\end{array}$} & 3 & Fire pit $(\mathrm{F} 13 ?)^{\mathrm{b}}$ & Charcoal & A.D. $1297 \pm 73$ (NZ) \\
\hline & & Fire pit (F8) & Charcoal & A.D. $1470 \pm 70$ (ANU) \\
\hline $\begin{array}{l}\text { Ngati Tiare } \\
\text { (RAR-40) }\end{array}$ & $\begin{array}{c}\text { Modern } \\
\text { drain }\end{array}$ & $\mathrm{N} / \mathrm{a}$ & Charcoal & A.D. $1494 \pm 71(\mathrm{NZ})$ \\
\hline RAR-51/10 & & Fire pit & Charcoal & A.D. $1750 \pm 90$ (ANU) \\
\hline \multirow[t]{2}{*}{ RAR-53/6 } & & Interface between subsoil & Charcoal & A.D. $1686 \pm 76(\mathrm{NZ})$ \\
\hline & & and topsoil & Charcoal & A.D. $1724 \pm 68$ (NZ) \\
\hline RAR-53/6 & & Fire pit (umu1) & Charcoal & A.D. $1337 \pm 62$ (NZ) \\
\hline RAR $-53 / 2$ & & Fire pit & Charcoal & A.D. $1500 \pm 60$ (NZ) \\
\hline RAR $-53 / 2$ & & Fire pit & Charcoal & A.D. $1620 \pm 60$ (NZ) \\
\hline MAN-92 & 2 & Fire pit (fe. 76) & Charcoal & A.D. $1655(\mathrm{BA})$ \\
\hline MAN-97 & $1 \mathrm{~b}$ & Fire pit (fe. 14) & Charcoal & A.D. $1675-1770(\mathrm{BA})$ \\
\hline MAN-95 & 1 & Oven rakeout & Charcoal & A.D. $1650-1900$ (BA) \\
\hline MKE1 & 4 & & Shell & A.D. 1301-1406 (NZ) \\
\hline MKE1 & 4 & & Shell & A.D. $1360-1434$ (NZ) \\
\hline MKE1 & 4 & & Shell & A.D. $1348-1424$ (NZ) \\
\hline MKE1 & 4 & & Shell & A.D. $1307-1422$ (NZ) \\
\hline MKE1 & 2 & & Shell & A.D. $1415-1475$ (NZ) \\
\hline
\end{tabular}

${ }^{a}$ All ages are calibrated.

b "In addition, charcoal from this structure gave a ${ }^{14} \mathrm{C}$ date of A.D. $1297 \pm 73$ (NZ1274)" (Bellwood 1978:70).

adze manufacturer and/or carver. Whether Structures 4 and 5 represent common remains of households at this time on Ma'uke will require further research, but it is clear that someone in the household made fishhooks and fished. Therefore these two households do represent at least two (male) social personae, with little evidence for inequality between them. Excavations large enough to reveal any other structures associated with these household units would assist in evaluating the inequality between the households, or if such markers were evident at this time in Ma'uke prehistory.

Layers 3 and 4 at the Ngati Tiare site contained many fire pits. No structure was evident in Layer 4, although a coral pavement was identified. One sleeping house may have been present in Layer 3 with an associated cookhouse. Without other households to compare these remains with evidence about heterogeneity and inequality are not available for this site at this time period. As at Anai'o, both fish hook manufacture and at least adze use took place at the Ngati Tiare site. Similar activities were conducted at these two sites on two different islands. The Anai'o site indicates at least two social personae and no evidence of inequality between them. Fishing was an important activity and fishhooks were manufactured at both sites. Stone tools (adzes) were used at Ngati Tiare but no evidence of manufacture was evident, while at Anai'o adzes were probably manufactured as well as used. Residents of two households seem to have manufactured fishhooks, while only one area shows evidence of adze manufacture. Basalt flakes were used at both sites, probably for vegetable and/or animal material processing. 
Table 6. Structural Remains at Cook Island Habitation Sites

\begin{tabular}{|c|c|c|c|c|c|c|c|c|c|}
\hline SITE & & $\begin{array}{l}\text { POSTHOLES } \\
(\#)^{\mathrm{a}}\end{array}$ & $\begin{array}{c}\text { GRAVEL } \\
\text { PAVING } \\
\text { (AREA } \\
\text { INDICATED) }\end{array}$ & PAVING STONES (AREA) & $\begin{array}{c}\text { CURB } \\
\text { STONES }\end{array}$ & $\begin{array}{c}\text { FIRE PITS } \\
(\#)\end{array}$ & $\begin{array}{l}\text { PITS } \\
(\#)\end{array}$ & MIDDEN & OTHER \\
\hline \multirow{3}{*}{$\begin{array}{l}\text { RAR-40 } \\
\text { (Ngati } \\
\text { Tiare) }\end{array}$} & Layer 4 & & & & & $\begin{array}{l}6 \text { (1 without } \\
\text { stones) }\end{array}$ & 1 & Oven rakeout & \\
\hline & Layer 3 & $7^{\mathrm{b}}$ & & $\begin{array}{l}50 \mathrm{~cm} \times 60 \mathrm{~cm}(\mathrm{~F} 10) \\
60 \mathrm{~cm} \times 50 \mathrm{~cm}(\mathrm{~F} 9) \\
100 \mathrm{~cm} \times 90 \mathrm{~cm} \\
\quad(\mathrm{~F} 12)^{\mathrm{c}}\end{array}$ & & 2 & 1 & $\begin{array}{l}\text { Mussel shells, pig } \\
\text { bone }\end{array}$ & \\
\hline & Layer 2 & 5 & $\begin{array}{l}\text { c. } 90 \mathrm{~cm} \times \\
200 \mathrm{~cm}\end{array}$ & $\begin{array}{l}\text { Coral stones included } \\
\text { in paving }\end{array}$ & & 1 & & & \\
\hline RAR-51/10 & & 13 & & $5.5 \times 9.5 \mathrm{~m}$ & Present & 1 & & & Paved path \\
\hline RAR-53/6 & Western & & & $7 \mathrm{~m}^{2}$ (2 terraces) & Present & & & & $\begin{array}{l}\text { The site consists of three } \\
\text { discrete units, the west } \\
\text { and central with two } \\
\text { paved terraces and the } \\
\text { eastern with one paved } \\
\text { terrace and one earthen }_{\text {terrace }}{ }^{\mathrm{d}}\end{array}$ \\
\hline RAR-53/6 & Central & 31 & & $\begin{array}{l}14 \times 2 \mathrm{~m} \\
14 \times 3 \mathrm{~m}\end{array}$ & Present & $2^{\mathrm{e}}$ & & & \\
\hline RAR-53/6 & Eastern & & & $9 \times 3 \mathrm{~m}$ & Present & & & & \\
\hline RAR-53/1 & & & & & Present & & & & $9 \mathrm{~m}$ long earthen terrace \\
\hline RAR $-53 / 2$ & & & & $9 \times 5 \mathrm{~m}$ & Present & & & & \\
\hline RAR $-53 / 3$ & & & & $5 \times 3 \mathrm{~m}$ & Present & & & & Paved path \\
\hline RAR-53/4 & & & & $16 \times 3 \mathrm{~m}$ & Present & & & & $\begin{array}{l}11 \times 4 \text { m earthen terrace } \\
3 \text { subsidiary small terraces }\end{array}$ \\
\hline Vaikura $^{\mathrm{f}}$ & & $50(56)$ & & Yes (area not available) & Present & 2 & 6 & & Paved path \\
\hline 'Are Rangis' & & Yes & Yes & Yes (area not available) & & & & & Paved path \\
\hline
\end{tabular}




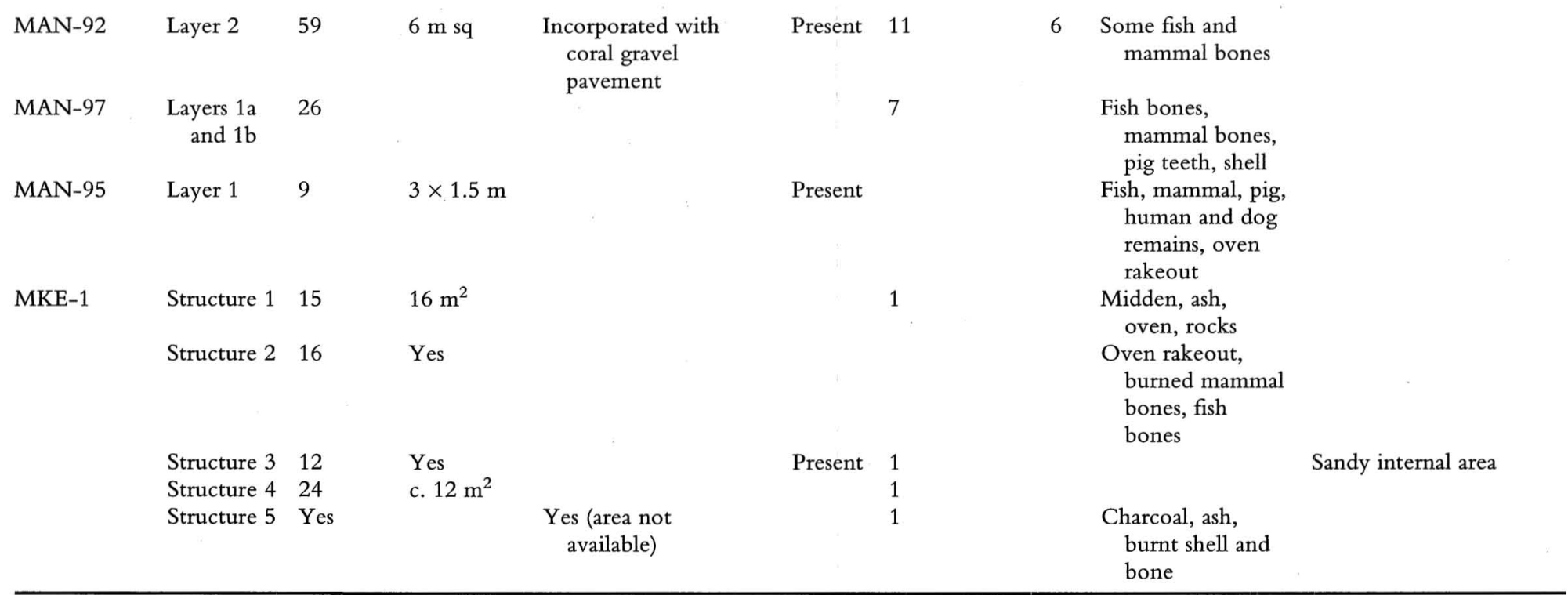

a The designations "postholes," "fire pits," and "pits" are taken at face value from the respective authors. The basis for these designations is described for the Mangaian sites.

${ }^{b}$ Four of these postholes indicated a habitation and three a cookhouse. See Bellwood 1978:66, 70.

${ }^{c}$ These measurements are approximate, as none are given in the report and they are taken from Fig. 40 (Bellwood 1978:66). Bellwood designates these as thresholds to structures, F9 and F10 opposing thresholds to a habitation and F12 a threshold to an adjacent cookhouse (1978:70). F10 consisted of both coral and basalt, while F9 was made of basalt alone.

${ }^{\mathrm{d}}$ Bellwood referred to these units as paepae; only the upper terrace of the central one was excavated.

e These fire pits pre-date the construction of the structure, and Bellwood argues represent a terrace that was removed when the terrace for the structure was cut $(1978: 48)$.

$\mathrm{f}$ There is almost no indication of how many postholes were present in each layer, certainly not enough information for separate reporting here. As discussesd in the text, the six features that this author would identify as large postholes adjacent to the pavement were identified as pits by Parker.

$\mathrm{g}$ No figures, measurements, or posthole counts were provided in the text for this site, therefore only the presence of features can be noted. 
Considerably more late prehistoric households have been excavated in the Southern Cook Islands. The two household units excavated on Mangaia Island indicate at least two social personae, one a carver and probable adze maker, the other not. The other household (MAN-92) had an additional structure to the sleeping house and $u m u$, probably a supported roof to shade activities on the pavement. The calcite upright at MAN-92 might indicate some special status in the household. Insufficient information is available about MAN-97 to discuss the social personae represented, but it followed the pattern noted at MAN-92 of artifacts clustered around fire pits. There are at least two and possibly three social personae represented by the sites on Mangaia. The surface remains of households on Rarotonga in the form of paepae, paved walkways, and terraces indicate several social personae and probably differential access to labor. Few artifacts were recovered from the foundations of sleeping houses or the pavements in front of them in excavations on Rarotonga. These were probably not the residences of craft specialists. Layer 2 at the Ngati Tiare site contained more artifacts than most of the other late prehistoric sites on Rarotonga. The artifact numbers are comparable to those of MAN-92 on Mangaia and probably do not represent the residence of an adze maker. The differences between Ngati Tiare Layer 2 and other late prehistoric sites on Rarotonga in terms of artifacts may be a result of differences in which areas of household units were excavated. It is unlikely to be the result of environmental factors at these sites as the sediment deposited at Ngati Tiare by the Vaikapuangi stream is the same clay that is present at the other Rarotongan sites.

The remains of the earlier households on $\mathrm{Ma}$ 'uke indicate several social personae, but no strong evidence of inequality. The later households on Mangaia again indicate several social personae but little inequality. The late prehistoric household units on Rarotonga probably represent more social personae than have yet been documented on the other islands and greater inequality. The standardization of house forms may indicate greater social integration on Rarotonga than on either Mangaia or Ma uke. To date there is no evidence of such standardization on these two islands, but the sample sizes are much smaller than those from Rarotonga are.

The extent of contact among these islands prior to the arrival of Europeans is a somewhat open question. The Mangaian oral traditions indicate a conscious cessation of contact with other islands, although there are oral traditions referring to sporadic interisland contact. Archaeological remains from deep deposits at MAN-44, a rock shelter on Mangaia excavated by Kirch and associates (see Kirch et al. 1995), included large pearl shells (Pinctada sp.) that could not grow on Mangaia's limited reef as well as basalt adzes with chemical signatures matching basalt from Tutuila, American Samoa. The oral traditions of Ma'uke, Mitiaro, and Atiu indicate that these three islands, collectively known as Ngaputoru, were socially interrelated throughout prehistory. However, in the late prehistoric era Mangaia, Rarotonga, and Ngaputoru were probably largely societies unto themselves and did not interact much with one another. It is not even evident that they traded among the islands for goods produced on any one but not on the others. The comparison here is among three largely self-sufficient island societies related through shared histories and interaction at one point in time but not socially or politically integrated in late prehistory. 
The available archaeological data for household remains in the Southern Cook Islands show variability beyond what would be expected from variable depositional environments. This type of variation is crucial to discussions of social organization at any one point in time, and to discussions of change through time. A "characteristic" household description may be convenient for the archaeologist, but the resulting descriptions of social organization are rather dull and unrealistic. Households also provide the best opportunity for comparison between islands and between types of social organization, as all people build or use some sort of shelter. Spatial organization is one of the most basic human cognitive abilities, and households the most basic spatial manifestation of social organization.

\section{ACKNOWLEDGMENTS}

Funding for the Mangaia research discussed in this paper was provided by the National Science Foundation Dissertation Improvement Grant program, the Stahl Foundation of the University of California, Berkeley, Valerie Mates, and the University of California Research Expeditions Program. The Cook Islands Government granted permission for the Mangaia research through the Research Council. The assistance and friendship of Tere Bishop, former Chair and Secretary of the Council, Tony Utanga, and the late Kauraka Kauraka has been invaluable. I am grateful to the Mangaia Island Council and Chief Administrative Officer Papamama Pokino for granting me permission to work on Mangaia, and to Mayor Tua Uria, for his support. My deepest appreciation to the kovana and families of Veitatei and Keia districts on Mangaia for allowing me to dig holes in the ground of those two valleys. My Mangaian field crew, Patrick Kirch and other members of my committee, and archaeological faculty and graduate students at the University of California, Berkeley, family, and friends have all provided encouragement and assistance in my research on Mangaia and the Cook Islands. Many people have contributed to the gathering of the data used in this paper, but the conclusions drawn from it and any errors therein are mine alone.

\section{NOTES}

1. The same rationale was at work in Europe and early America in the practice of apprentices living in the household of their master, where they could learn intimately the details of the craft as well as being present to assist at all times.

2. Savage's dictionary was of Rarotongan Maori. On Rarotonga the ariki were the highest ranking hereditary chiefs of the extended kin group, each of which had an ariki. Mata'iapo and rangatira were lower ranking leaders within the kin group.

3. Only recorded surface structural remains were used in determining the area at these sites. Residential sites that did not make extensive use of stone often had smaller areas but may in reality turn out to have equal or larger areas than those that did.

4. All of the radiocarbon dates reported by Walter are on shell using a delta-R factor derived from the Society Islands area. As upwelling rates can vary across the ocean (see Dye 1994) the accuracy of these results remains to be tested by paired samples of shell and charcoal from the Southern Cook Islands. For the purposes of this paper the dates given by Walter will be used for this site.

\section{REFERENCES}

BANNING, E. B., AND.B. F. Byrd

1987 Houses and the Changing Residential Unit: Domestic Architecture at PPNB 'Ain Ghazal, Jordan: 84-92, in S. MacEachern, D. Archer, and R. Garvin, eds. Households and Communities. Proceedings of the 21st Annual Chacmool Conference. Calgary: The Archaeological Association of the University of Calgary. 
Beaglehole, J. C., ed.

1967 The Journals of Captain James Cook on his Voyages of Discovery. The Voyage of the Resolution and Discovery 1776-1780. Part Two. Cambridge: Hakluyt Society.

BELlwOOd, P. S.

1978 Archaeological Research in the Cook Islands. Pacific Anthropological Records 27. Honolulu: Bishop Museum.

Bourdieu, $\mathrm{P}$.

1972 Outline of a Theory of Practice. Cambridge: Cambridge University Press.

BRUMFIEL, E.

1992 Breaking and entering the ecosystem - gender, class, and faction steal the show. American Anthropologist 94:551-567.

CORDY, R.

1981 A Study of Prehistoric Social Change: The Development of Complex Societies in the Hawaiian Islands. New York: Academic Press.

DEETZ, J.J.F.

1982 Households: a structural key to archaeological explanation, in Archaeology of the Household: Building a Prehistory of Domestic Life: 717-724, ed. R. Wilk and W. Rathje. American Behavioral Scientist $25: 6$.

Douglass, $\mathrm{B}$.

1979 Rank, power and authority: A reassessment of traditional leadership in South Pacific societies. The Journal of Pacific History 14(1):2-27.

DYE, T.

1994 Apparent ages of marine shells: Implications for archaeological dating in Hawai'i. Radiocarbon 36(1):51-57.

ENDICOTT, J. M.

2000 Archaeological Analysis of Prehistoric Social Organization on Mangaia Island, Cook Islands. Unpublished Ph.D. diss. University of California, Berkeley.

GILL, W. W.

1876 Life in the Southern Isles; or Scenes and Incidents in the South Pacific and New Guinea. London: Religious Tract Society.

1894 From Darkness to Light in Polynesia, with Illustrative Clan Songs. London.

GOLDMAN, I.

1970 Ancient Polynesian Society. Chicago: University of Chicago Press.

Green, R. C.

1984 Settlement patterns in Oceania: An introduction to a symposium. New Zealand Journal of Archaeology 6:59-60.

1991 The study of open settlements in New Zealand prehistory, in The Archaeology of the Kainga: A Study of Precontact Maori Undefended Settlements at Pouerua, Northland, New Zealand: 23-32, ed. D. G. Sutton. Auckland: Auckland University Press.

Hiroa, T. R. (Sir Peter Buck)

1934 Mangaian Society. B. P. Bishop Museum Bulletin 122. Honolulu.

1944 Arts and Crafts of the Cook Islands. B. P. Bishop Museum Bulletin 179. Honolulu.

n.d. Unpublished field notes on file at the Bernice P. Bishop Museum archives, Honolulu.

HODDER, I.

1986 Reading the Past: Current Approaches in Interpretation in Archaeology. Cambridge: Cambridge University Press.

1990 The Domestication of Europe. Oxford: Basil Blackwell.

Jennings, J., R. Holmer, J. Janetski, And H. Smith

1976 Excavations on Upolu, Western Samoa. Pacific Anthropological Records 25.

KENT, S.

1984 Analyzing Activity Areas: An Ethnoarchaeological Study of the Use of Space. Albuquerque: University of New Mexico Press.

KIRCH, P. V.

1984 The Evolution of Polynesian Chiefdoms. Cambridge: Cambridge University Press. 
2000 On the Road of the Winds: An Archaeological History of the Pacific Islands before European Contact. Berkeley: University of California Press.

Kirch, P. V., D. W. Steadman, V. L. Butler, J. Hather, and M. I. Weisler

1995 Prehistory and human ecology in eastern Polynesia: Excavations at Tatagatatau Rockshelter, Mangaia, Cook Islands. Archaeology in Oceania 30:47-65.

McCoy, P. C.

1973 Excavation of a rectangular house on the east rim of Rano Kau Volcano, Easter Island. Archaeology and Physical Anthropology in Oceania 8:51-67.

1976 Easter Island Settlement Patterns in the Late Prehistoric and Proto-historic Periods. International Fund for Monuments, Easter Island Committee. Bulletin 5.

MCGuire, R. H.

1983 Breaking down cultural complexity: Inequality and heterogeneity, in Advances in Archaeological Method and Theory, Vol. 6, ed. M. Schiffer. New York: Academic Press.

MoOre, H.

1986 Space, Text and Gender. Cambridge: Cambridge University Press.

Moyle, R. M., ED.

1984 The Samoan Journals of John Williams. Pacific History Series No. 11. Canberra: Australia National University Press.

Prickett, N. J.

1982 An archaeologist's guide to the Maori dwelling. New Zealand Journal of Archaeology 4:111-147.

SAHLINS, M.

1958 Social Stratification in Polynesia. Seattle: American Ethnological Society.

Savage, Stephen

1990 A Dictionary of the Maori Language of Rarotonga. Dept. of Island Territories, Wellington. Republished by the Institute of Pacific Studies, University of the South Pacific, Suva.

Sutton, D. G.

1991 Conclusion: Interpretation and implications, in The Archaeology of the Kainga: A Study of Precontact Maori Undefended Settlements at Pouerua, Northland, New Zealand: 183-208, ed. D. G. Sutton. Auckland: Auckland University Press.

Sutton, D. G., ED.

1991 The Archaeology of the Kainga: A Study of Precontact Maori Undefended Settlements at Pouerua, Northland, New Zealand. Auckland: Auckland University Press.

Thomas, N.

1989 Out of Time: History and Evolution in Anthropological Discourse. Cambridge: Cambridge University Press.

Trotter, M. M., eD.

1974 Prehistory of the Southern Cook Islands. Bulletin of the Canterbury Museum 6. Christchurch.

WALTER, R.

1993 The community in Ma'uke prehistory, in The Evolution and Organisation of Prehistoric Society in Polynesia: 72-86, ed. M. Graves and R. Green. New Zealand Archaeological Association Monograph 19.

WEEKS, M. J.

1988 Residential and Local Group Organization in the Maya Lowlands of Southwestern Campeche, Mexico: The Early Seventeenth Century: 73-97, in Household and Community in the Mesoamerican Past, ed. R. Wilk and W. Ashmore. Albuquerque: University of New Mexico Press.

WEISLER, M. I., and P. V. KIRCH

1985 The structure of settlement space in a Polynesian chiefdom: Kawela, Molokai. New Zealand Journal of Archaeology 7:129-158.

WILLIAMS, J.

1840 A Narrative of Missionary Enterprises in the South Sea Islands; with Remarks upon the Natural History of the Islands, Origin, Languages, Traditions and Usages of the Inhabitants. London: John Snow. 


\section{ABSTRACT}

Polynesian and other Oceanic societies have often informed research into social complexity. McGuire (1983) has proposed a means of measuring complexity that does not assume any particular organizational form. The examination of prehistoric household remains allows archaeologists to compare common units of social organization across societies for more meaningful comparisons of past social organization. This paper discusses house remains excavated on three islands in the Southern Cook Islands of central Polynesia for the information they provide about past social organization on the islands and provides comparison between three closely related island societies. KEYwords: Southern Cook Islands, households, complexity, social organization. 